\title{
АНАЛІТИЧНА ФІЛОСОФІЯ ЯК НОВА ПАРАДИГМА РАЦІОНАЛІЗМУ В ФІЛОСОФІї ХХ СТОРІчЧЯ
}

\author{
Л.В. Кулабухова
}

\begin{abstract}
Візьмемо, наприклад, до рук яку-небудь книгу з богослов'я або шкільної метафізики та запитаємо: чи $€$ в ній будь-яке абстрактне міркування про кількість та число? Нi. Чи є в ній будь-яке обгрунтоване досвідом міркування про факти та існування? Ні. Так викиньте її у полум'я, бо в ній не може бути нічого, крім софістики та помилковості.
\end{abstract}

Девід Юм

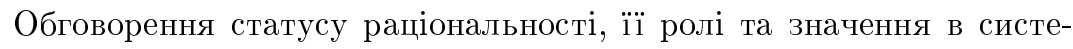
мі свідомості та людської життєдіяльності, відношення до освоєння дійсності, є у теперішній час одною з найбільш актуальних тем як у вітчизняній так і зарубіжній літературі.

Безумовно, суперечки про значимість інтелектуально-раціонального відношення до світу почались з часів, коли інтелект та раціональне мислення виступили як самостійний фактор культури. Проблеми раціональності зараз пов'язані з особливостями розвитку науково-технічної цивілізації, початком якої є тип реформаторського відношення людини до світу.

На наш погляд, для дослідження проблеми раціональності як філософсько-світоглядної проблеми необхідно залучити міждисциплінарний підхід та розглянути проблему раціональності у широкому істо-

Актуальні проблеми духовності

(Відп. ред.: Я.В. Шрамко)

Кривий Ріг (2007), 118-124 
рико-філософському контексті. Зокрема, для експлікації поняття раціональності, важливо пояснити «семантику» слова «ratio» у ході історичного процесу розвитку науки і культури. На жаль, у нас немає достатньо докладних досліджень розвитку філософської мови, тому ми не маємо чіткої картини еволюції багатьох філософських термінів як то «інтелект», «мислення», «розум», «розсудок», як вони виникали та еволюціонували на підгрунті національних мов [7].

Початкове значення ідеї раціональності відкрилось давньогрецькій філософській свідомості. Подальшого розвитку цей термін зазнав у добу середньовіччя з визнанням значущості раціонального для вдосконалення релігійної свідомості, коли виник розподіл на два табори: «просто віруючих» та «розуміючих» (тобто таких, які потребують критичного усвідомлення того, у що потрібно вірити).

Починаючи з другої половини XIX сторіччя в світовій філософії відбувалось посилення метафізичного мислення та філософського ірраціоналізму. Ряд дослідників розглядають містику як складну духовну традицію, в котрій поєднані різні, іноді протилежні тенденції. На думку Гуревича, вона претендує на володіння солідним прогностичним потенціалом. Він вважає, що містична свідомість за допомогою інтуїції намагається вловити споконвічну єдність усіх речей. Містичне ставлення до дійсності виникає з передумови, що у природи можливо вирвати деякі таємниці, до яких наука та супровідний їй тип раціональності приходять аналітичним та експериментальним шляхом [1]. А отже, згідно з такою точкою зору, філософія зараз знаходиться на шляху пошуку нового типу раціональності, який би включав елементи ірраціонального.

Одночасно з'явились течії, які визнавали ідеї метафізики сумнівними і такими, що суперечать досвідному пізнанню. Свій внесок в протидію ірраціональним тенденціям зробила аналітична філософія, завдяки розвитку сучасної символічної логіки. У XX сторіччі виникають різні центри та школи аналітичної філософії, зокрема «Віденський гурток». Слід зауважити, що багато членів цього інтелектуального співтовариства не були «чистими» філософами, всі вони працювали у конкретних галузях науки і спочатку не мали єдиних філософських переконань. Проте, їх загальною метою був пошук раціонального обгрунтування філософії та звільнення її від метафізики. Своїм завданням Віденський гурток вбачав розробку ідейної зброї сучасного емпіризму, як то:

- наголошення на відсутності для наукового світосприйняття не- 
розв'язуваних загадок;

- застосування методу логічного аналізу мови;

• розробку емпіристичної та позитивістської теорії пізнання;

- прагнення до єдиної науки [3].

Протягом XX сторіччя аналітична філософія не тільки не втрачає своїх позицій, а, навпаки, завойовує нові площини у Європі та США, витісняючи континентальну філософію (див. [5]). Аналітична філософія розвивається, виходячи не тільки з теоретичних завдань, але маючи за мету практичне її застосування в інших науках. Обговорення всієї цієї проблематики знайшло відображення не тільки у філософії, a і в математиці, теорії комунікації, лінгвістиці.

Проте, аналітична філософія вбачає свою мету не у головуванні над усіма науками, а у поясненні та уточненні виразів та аналізу мови. Вона будує свої ствердження, базуючись на символічній логіці, залучаючи до цього мову, що і є інноваційним напрямком. Логіка стверджує, що мова - це лише зовнішній процес, пов'язаний тільки з процесом передачі думок, але не з їх формуванням. «Вважається, що мова лише виражає те, що вже в головних рисах склалося без допомоги мови. Формування мислення - це, так би мовити, самостійний процес, ніяк не пов'язаний з природою конкретних мов» [6].

Згідно цієї теорії, різні мови - це в основному паралельні способи вираження одного і того ж понятійного змісту, і тому вони, в принципі, відрізняються лише несуттєвими деталями. Символічна логіка, філософія та інші науки - це не особливі відгалуження мови, а системи, які протистоять мові і мають справу безпосередньо зі сферою чистого мислення. Вчені цікавляться основою явищ, які дозволяють виявити тісний зв'язок між фактами, які залишаються в тіні. Ця діяльність у подальшому може підлягати значним змінам. При вивченні основи мовних явищ, які використовуються для оцінювання наукових теорій та результатів, науковці повинні досягти згоди і така згода досягається за допомогою мовних процесів.

Ми розглядаємо світ у напрямку, який підказує нам рідна мова, виділяємо ті чи інші категорії та типи не тому, що вони самоочевидні, а через призму мовної системи у нашій свідомості. Це має важливе значення для сучасної науки, адже тут ми зтикаємось 3 новим принципом відносності, який стверджує, що подібні фізичні явища дозволяють створити подібну картину всесвіту тільки при подібності мовних 
систем. Це може бути не таким очевидним, якщо порівнювати лише групи індоєвропейських мов, які будувалися на загальній культурі, розвинутій під впливом латини та грецької. Тому поняття «всі вчені, які говорять індоєвропейськими мовами» та «Всі вчені» не співпадають. Якщо ж турецькі або китайські вчені описують світ подібно до їх європейських колег, то це означає тільки те, що вони цілком перейняли західну систему мислення. При співставленні наших мов з іншими, які розвивалися незалежно одна від одної та старого світу, можна прийти до висновку, що:

- мови розглядають світ по-різному;

- всі понятійні системи мають залежність від мови [6].

Для розуміння слова або фрази та правильного їх перекладу важливо враховувати і соціо-культурний аспект. На жаль, не зважаючи на панування аналітичної філософії у США та багатьох країнах Європи, вона не набула такого поширення в Україні, можливо навіть сказати, що українська філософія тільки починає своє знайомство 3 нею, будучи тривалий час затиснутою в рамках ідеології. Інший фактор - це недостатня розвинутість економіки України, який, на наш погляд, також певним чином впливає на розвиток філософської думки. Безумовно пояснити це стає можливим, припускаючи, що існують визначені детермінанти соціо-культурного плану. Тому стиль мислення, скажімо, в німецькій філософській культурі інший, аніж у французькій, що у відомій мірі залежить від особливостей національних мов цих народів, хоча первісні методології формальної логіки - верифікація, фальсифікація та інші є загальними для аналізу багатьох мов.

Усвідомлення залежності всіх наших знань від мовних засобів, які до сих пір відкриті пізнанню, і зумовило виникнення методологічної системи, яка намагається поєднати мову та науку, очистити науку від неточностей та багатозначностей. Це, в свою чергу, призвело до виникнення «лінгвістичного повороту» у аналітичній філософії.

Загальновідомо, що мова відображає масове мислення, реагуючи на всі нововведення та зміни. Згідно теорії Б. Уорфа, природна направленість семантичних змін у мовах полягає у тому, що об'єктивне сприйняття первісне у відношенні до суб'єктивних. Зокрема, узагальнюючи свої ідеї, зокрема під час вивчення світогляду та мов деяких відокремлених народів, чий побут та рівень розвитку суттєво відрізняється від побуту європейців, Уорф прийшов до висновку, що поняття «часу» та «матерії» не надані з досвіду, вони залежать від природи 
мови. Поняття «простір» тісно пов'язане з паралельним вживанням інших категорій мислення, як то «час» та «матерія». Цей зв'язок існує не тільки тоді, коли ми концентруємо увагу на суто лінгвістичних параметрах, скільки тоді, коли ми вивчаємо культуру і мову як щось цілісне, у якому існує взаємозв'язок, і він має бути виявлений.

Аналітичний філософ повинен не просто проголошувати ті чи інші філософські положення, але в першу чергу висувати чіткі доводи (обгрунтування) цих положень, що неминуче вимагає експлікації їх логічних взаємозв'язків та випробування на стійкість, з точки зору можливого спростування [9].

Р. Карнап у своїй праці «Подолання метафізики шляхом логічного аналізу мови» на конкретних прикладах обгрунтовує думку про те, що метафізичні поняття - це псевдопоняття i «у логічно вірно побудованій мові метафізика зовсім не могла б знайти вираження» [2]. Усі метафізичні помилки, на думку Карнапа, спираються на логічні дефекти, зокрема пов'язані з дієсловом «бути» та його багатозначністю. Багато аналітичних філософів розглядають себе як продовжувачі раціоналістичної традиції у світовій філософії, представленій такими великими іменами, як Аристотель, Фома Аквінський, Декарт, Лейбниць, Кант.

Як, наприклад, стверджує Р.Рорті: «Аналітичну філософію можливо приблизно визначити як спробу з'єднати перехід від обговорення досвіду до обговорення мови - те, що Густав Бергман назвав «лінгвістичним поворотом» - 3 черговою спробою професіоналізувати цю дисципліну роблячи її все більш науковою. Лінгвістичний поворот притаманний усій філософії XX сторіччя» (Цит. за: [8, с. 85]). Лінгвістичний поворот виник як інноваційний напрямок у аналітичній філософії (див. [4]), згідно з яким філософські питання вирішуються більш точною інтерпретацією мовленнєвих виразів. У соціальній теорії термін «лінгвістичний поворот» викликав багато протиріч. Згідно Ентоні Гідденса, зосередження на епістемологічних питаннях відвертає увагу від більш «онтологічних» проблем соціальної теорії. «Ніж займатися епістемологічними диспутами ... потрібно сконцентруватися на переробці концепцій людського буття та людських діянь, соціальній репродукції та трансформації [10, с. 2]. Водночас, Ентоні Гідденс вважає термін «лінгвістичний поворот» у деякій мірі помилковим. «Найважливіші досягнення у соціальній теорії відносяться не стільки до змін у мові, як до змін у поглядах на точку перетину між сказаним (визначеним) та зробленим... Радикальна трансмутація герменевтики та феноменології, ініційована Хайдеггером, наразі з іноваціями пізнього Вітгенштейна - $\epsilon$ двома основними сигнальними маркерами нового 
шляху» [10]. Наряду з цим поглядом існують інші. Д. Фьоллесдаль вважає, що помилковою є традиційна класифікація сучасної філософії, де аналітична філософія вбачається як окремий напрямок. «Можливо бути і аналітичним філософом і феноменологом, і екзистенціалістом або герменевтиком, тощо. Існують більш або менш аналітичні феноменологи» $[9$, с. 15$]$. Аналітична філософія пов'язана із соціальною етикою. У філософських працях ми підкреслюємо визначну роль, яку відіграють аргументація та обгрунтування.

Не слід тлумачити лінгвістичний поворот у тому сенсі, що центральним розділом аналітичної філософії $\epsilon$ нібито філософія мови. Аналіз мови виступає тут, у першу чергу, як спосіб аналізу філософських проблем по суті.

Намагаючись надати оцінку лінгвістичному повороту як явищу в аналітичній філософії, явищу, єдиному в своїй різноманітності, стає можливим підвести підсумки, що не існує єдиних рис, що визначають аналітичний рух. Лінгвістичний поворот поставив перед собою два головних завдання:

- критичне - завдання аналізу і вирішення суперечок та непорозумінь;

- доповнююче- привертання уваги до процесу вживання слів або граматики та логіки мови.

Отже, лінгвістичний поворот - це, свого роду, реакція на визначення філософії як дисципліни, що намагається вирішити традиційні проблеми у спосіб, який не суперечить здоровому глузду.

\section{1 Бібліографія}

[1] Гуревич В.С. Поиск новой рациональности // Рациональность какпредмет философского исследования (под ред. Пружинина Б.И., Швырева В.С.) - М., 1995. - С. 179-180.

[2] Карнап P. Преодоление метафизики путем логического анализа языка // Вестник МГУ 1993. Серия 7: Философия - №6. - С. 1126.

[3] Карнап Р. Ган Г. Нейрат О. Научное миропонимание- Венский кружок // Актуальні проблеми духовності.-Вип. 6. - Кривий Ріг: КДПУ, 2005. - С. 197-214. 
[4] Кулабухова Л.В. Лингвистический поворот и его значение для аналитической философии // Актуальні проблеми духовності. Вип. 7. - Кривий Ріг: КДПУ, 2006. - С. 155-164.

[5] Россман В., Шрамко Я.В. О философии континентальной и аналитической и об интеллектуальной многоукладности // Вопросы философии. - 2002. - № 11. - С. 106-123.

[6] Уорф Б. Наука и языкознание // Новое в лингвистике.- М., 1960. - Вып. 1. - С.92-106.

[7] ШІвырев B.C. Рациональность как философская проблема // Рациональность как предмет философского исследования (под ред. Пружинина Б.И., Швырева В.С.) - М., 1995. - С. 1-17.

[8] Шрамко Я.В. Что такое аналитическая философия? // Актуальні проблеми духовності. - Вип. 7.-Кривий Ріг: Видавничий дім, 2006. - C. 165-188.

[9] Follesdal D. Analytic philosophy: what is it and why should one engage in it? // Glock H. - J. (ed.) The Rise of Analytic Philosophy. Blackwell Publishers, 1997.- P.1-16.

[10] Giddens A. The Constitution of Society. University of California Press, 1984. Extracts and Annotations. - P. 1-10. 